\title{
doispontos:
}

\section{Representação e consciência na metapsicologia freudiana}

\author{
Fátima Caropreso ${ }^{1}$ \\ Universidade Federal de Juiz de Fora
}

\begin{abstract}
Resumo: Ao longo do desenvolvimento de sua teoria metapsicológica, Freud formulou diversas hipóteses para explicar como a consciência se relaciona com o restante do psiquismo e quais são suas condições de possibilidade. O problema da relação entre mente e consciência, na teoria freudiana, pode ser expresso como o da relação entre consciência e representação. No entanto, para que o alcance da contribuição freudiana possa ser avaliado, é necessária uma compreensão mais completa de todas as ramificações do problema da relação entre a representação e a experiência consciente. Essa compreensão tem que levar em conta como estas noções são concebidas nos diferentes momentos do desenvolvimento da metapsicologia. Esse artigo se propõe a trazer à luz as várias nuanças desse problema, nas diversas e intrincadas ramificações que ele apresenta como uma contribuição à compreensão da obra freudiana.
\end{abstract}

Palavras-chave: Psicanálise; Freud; metapsicologia; consciência; representação; inconsciente.

Abstract: Over the course of the development of his metapsychological theory, Freud formulated many different hypotheses to explain how consciousness is related to mind as a whole and what its conditions of possibility are. The problem of the relationship between mind and consciousness in Freud's theory can be presented as concerning the relationship between consciousness and representation. However, to evaluate the scope of Freud's contribution, a fuller understanding of all the branches of the problem of the relationship between representation and conscious experience is required. This understanding must take into account how these concepts are defined in the different stages of metapsychology's development. This paper sets out to bring the many shades of this problem to light, in the various and intricate branches it manifests, as a contribution to the understanding of Freud's work. Keywords: psychoanalysis; Freud; metapsychology; consciousness; representation; unconscious.

Na teoria psicanalítica freudiana, a definição do campo do psiquismo pela presença da consciência é recusada. No entanto, Freud nunca deixou de considerar a consciência como algo indispensável ao conhecimento da mente e, ao longo de grande parte de sua teoria metapsicológica, formulou hipóteses para explicar como ela se relaciona com o restante do psiquismo e quais são suas condições de possibilidade. Uma vez que, em sua teoria, o mental é, essencialmente, o representacional, o problema da relação entre mente e consciência pode ser expresso como o da relação entre consciência e representação. Natsoulas (2002) argumenta que Freud elaborou uma teoria sofisticada e inovadora da consciência. Gomes (2003) ressalta a relevância de se estabelecer uma relação entre a teoria freudiana da consciência e os desenvolvimentos recentes nas áreas da psicologia cognitiva, das neurociências e da filosofia da mente. No entanto, para que o alcance da contribuição freudiana possa ser avaliado, é necessária uma compreensão de todas as ramificações do problema da relação entre a representação e a experiência consciente, tal como estas são concebidas em diferentes momentos da metapsicologia construída por Freud. O que se observa, muitas vezes, na literatura da área, é uma apresentação sucinta das questões metapsicológicas, sem a explicação 
dos impasses, das contradições e das dificuldades teóricas que permanecem frequentemente implícitas na argumentação freudiana. Nesse artigo, pretendemos trazer à luz essas nuanças do problema, nas diversas e intrincadas ramificações em que ele se apresenta, como uma contribuição tanto à compreensão da obra freudiana quanto à contribuição para a psicologia contemporânea que dela se pode esperar.

A primeira reflexão freudiana sobre a consciência está presente no Projeto de uma psicologia, redigido em 1895 e publicado postumamente em 1950, texto no qual a noção de um psiquismo inconsciente é, pela primeira vez, claramente afirmada na teoria de Freud. Em Sobre a concepção das afasias (FREUD, 1891), ele ainda identificava claramente o psíquico ao consciente: todo processo psíquico, a partir do momento em que emergisse de seu substrato neural, seria necessariamente consciente. Nos textos dedicados à teoria e à clínica das neuroses produzidos nos anos seguintes, podemos perceber que essa identificação começa a ser progressivamente questionada (CAROPRESO, 2008a). No entanto, é apenas no Projeto que ela é cabalmente descartada. A partir daí, o psíquico passa a ser pensado como sendo, originalmente e em sua maior parte, inconsciente, e a consciência, por sua vez, é definida como uma qualidade que pode vir a se acrescentar, em determinadas condições, a somente uma parte dos processos mentais. Em seus textos metapsicológicos subsequentes, Freud dá continuidade à reflexão sobre o problema da relação entre a consciência e a representação iniciada em 1895. O objetivo deste trabalho é fazer uma análise detalhada de como a possibilidade da consciência de um processo psíquico é concebida na teoria metapsicológica freudiana do aparelho psíquico, dando assim continuidade ao exame do modo como o problema da consciência se formula e se desenvolve na obra de Freud (SIMANKE e CAROPRESO, 2005; CAROPRESO, 2008b; CAROPRESO, 2008c).

\section{REPRESENTAÇÃO E CONSCIÊNCIA NO PROJETO DE UMA PSICOLOGIA (1895)}

No Projeto, Freud se propõe a explicar a totalidade dos processos psíquicos partindo de dois postulados principais: o neurônio - que seria a unidade material e funcional do sistema nervoso ou do "aparelho neuronal" ${ }^{2}$ - e a quantidade - que é definida como algo que diferencia a atividade do repouso e que está submetida às leis gerais do movimento (a lei da inércia, sobretudo). A tendência primordial do aparelho - $o$ "princípio da inércia neuronal" - seria então, anular todo o aumento quantitativo, descarregando a quantidade recebida pela via mais direta possível. Essa tendência pode ser entendida como direcionada para evitar o desprazer, pois Freud identifica, nesse momento de sua teoria, o aumento no nível de excitação com o desprazer e a sua diminuição com o prazer. ${ }^{3}$ Se o aparelho recebesse apenas quantidades de origem externa ("quantidades exógenas", como diz Freud), seria possível, em princípio, por meio do movimento reflexo, descarregá-las totalmente e, assim, manter o sistema livre de qualquer aumento quantitativo permanente. Mas, além das quantidades exógenas, o aparelho neuronal receberia também quantidades endógenas de origem somática, e estas não poderiam ser suprimidas apenas através do mecanismo reflexo. Embora os movimentos reflexos funcionem como um meio de descarga para essas quantidades oriundas das necessidades vitais, eles não são capazes de afastar o organismo da fonte da estimulação, como podem fazê-lo, em princípio, com relação às quantidades exógenas provenientes do mundo físico. Em outras palavras, as respostas reflexas não permitem, nesse caso, a "fuga do estímulo".

O cancelamento de uma fonte interna de estímulos dependeria de uma atuação mais complexa sobre o mundo, como, por exemplo, aquela necessária para a obtenção de alimento, no caso da fome. Para que a estimulação endógena pudesse cessar, seria necessário o que Freud chama de uma "ação específica", a qual, devido à sua complexidade, teria como condição certo acúmulo de quantidade no aparelho, impondo uma modificação de sua tendência fundamental originária: em vez de trabalhar para manter o nível interno de quantidade igual a zero, a tendência dominante passaria a ser mantê-lo constante no nível mí- 
nimo necessário para a ação específica. Assim, o princípio de inércia daria lugar ao que Freud denomina "tendência à constância". No entanto, essa tendência não se oporia ao primeiro; ao contrário, atuaria em seu favor, criando condições para que a quantidade endógena fosse, de fato, descarregada da forma mais eficiente (pela satisfação da necessidade, por exemplo).

Três sistemas de neurônios comporiam o aparelho neuronal: o primeiro seria o sistema de percepção phi, cuja função seria receber as quantidades de estímulo provenientes da periferia do sistema nervoso e transmiti-las, enfraquecidas e fracionadas, ao sistema vizinho $p s i$; esse sistema $p s i$ seria um sistema de memória, onde se constituiriam as representações; o terceiro sistema - ômega - seria responsável pela consciência. Esses sistemas não se diferenciariam uns dos outros devido à natureza dos neurônios que os compõem, mas sim devido ao modo distinto de ação da quantidade em cada um deles. Entre os neurônios, haveria "barreiras de contato", as quais ofereceriam certa resistência à passagem da excitação de um neurônio para outro, fazendo com que apenas as quantidades cuja intensidade fosse superior à da resistência das barreiras conseguissem passagem. Quando isso ocorresse, a barreira de contato seria "facilitada", fazendo com que, numa segunda ocupação dos neurônios correspondentes, a resistência encontrada fosse menor, e a quantidade fluísse mais facilmente naquela direção. A facilitação diferenciada das barreiras de contato faria com que se constituíssem caminhos preferenciais no aparelho, os quais tornariam possível a memória, ensejando a repetição de processos anteriormente ocorridos. Apenas no sistema psi as barreiras de contato seriam capazes de oferecer resistência à passagem da excitação; no sistema de percepção $p h i$, a intensidade da quantidade recebida seria superior à da resistência das barreiras de contato, de modo que, nesse sistema, essas barreiras estariam totalmente facilitadas e, portanto, incapazes de exercer qualquer função: nos termos de Freud, phi seria um sistema completamente permeável à quantidade. Já em psi - que receberia a quantidade exógena indiretamente, através de phi-, as ocupações seriam menos intensas, devido ao fato de que a estrutura ramificada de phi faria com que a corrente excitatória se distribuísse ao longo de diversos caminhos neuronais, incidindo sobre psi em vários pontos. Assim, a cada aumento de quantidade em phi, o sistema de memória seria ocupado em vários pontos com intensidades menores, em vez de ser ocupado muito intensamente em um único ponto. Assim, a quantidade que alcançasse psi possuiria intensidade inferior à da resistência das barreiras de contato e, por isso, para conseguir abrir passagem, uma mesma barreira teria que ser afetada pela ocupação de dois ou mais neurônios simultaneamente.

Em cada passagem da quantidade pelas barreiras de contato, a resistência oferecida seria atenuada, de modo que, numa segunda ocupação da mesma barreira, a resistência encontrada seria menor. Assim, surgiriam caminhos preferenciais para o curso da excitação no sistema psi, os quais constituiriam a base da memória. Um circuito de neurônios ocupados, cujas barreiras de contato estivessem facilitadas entre si, constituiria uma representação, segundo o que se pode inferir daquilo que Freud aí propõe. Na ausência de uma ocupação atual, a representação continuaria existindo, por assim dizer, em potência, dado que as facilitações assegurariam a possibilidade de uma nova ocorrência do mesmo processo, isto é, elas tornariam possível uma nova ocupação do mesmo circuito e, com isso, assegurariam a possibilidade do ressurgimento da representação.

O sistema de memória estaria conectado, de forma direta, ao interior do corpo, de modo que sobre ele incidiria também a excitação somática de origem endógena. $\mathrm{O}$ modo de ação da quantidade endógena seria diferente daquele da exógena e, por esse motivo, Freud é levado a dividir o sistema psi em dois subsistemas: "psi do manto", que receberia quantidade exógena via phi e "psi do núcleo", que receberia quantidade endógena diretamente do interior do organismo. O conjunto de ocupações de psi do núcleo constituiria o que Freud então define como a parte constante do "eu". Este último seria o portador do armazenamento da constante de quantidade necessária para a satisfação das necessidades vitais, quantidade essa que seria 
por ele utilizada para direcionar os processos associativos, de modo a propiciar as condições para a satisfação e impedir ou fazer cessar a produção de desprazer.

De acordo com a teoria do aparelho neuronal, a constituição das representações precederia e seria independente da consciência. As representações se constituiriam no sistema de memória psi e apenas secundariamente, com o prosseguimento do processo até o sistema ômega - que estaria diretamente ligado a psi-, elas poderiam dar origem a qualidades sensoriais e, então, virem a se tornar conscientes. $\mathrm{O}$ sistema ômega produziria o que Freud chama de "signos de qualidade", que seriam, então, enviados a psi. A produção desses signos seria condição necessária para uma representação se tornar consciente, mas não seria condição suficiente: os signos recebidos pelo sistema de memória teriam que ser antes focalizados pelo mecanismo da "atenção" - que seria uma das funções do eu - para que a representação fosse de fato apreendida conscientemente. Se essa focalização pela atenção não ocorresse, mesmo tendo sido produzidos os signos de qualidade, a representação não alcançaria a consciência. ${ }^{4}$

Como Porchat (2005) analisa em detalhe, o mecanismo da atenção é definido de maneiras bastante diferentes nos diversos textos freudianos. No Projeto, Freud concebe a atenção como uma ocupação de signos de qualidade recebidos por psi do manto, uma ocupação que partiria do eu (isto é, do núcleo de psi) e seria condicionada biologicamente. Esse condicionamento biológico do eu, que o levaria a manter uma ocupação constante dos signos de qualidade, deve-se ao fato de que a falta dessa ocupação, em certos casos, levaria à produção de desprazer. A atenção consistiria, assim, na "segunda regra biológica" a regular os processos no aparelho neuronal, enquanto o abandono de caminhos que conduzem ao desprazer (a "defesa primária") consistiria na primeira dessas regras. ${ }^{5}$

No caso das representações constituídas a partir de estimulação proveniente do sistema phi, e não a partir de estimulação endógena via psi do núcleo, os signos de qualidade sempre seriam produzidos: Freud postula que, de alguma forma, a produção desses signos dependeria apenas das propriedades dos estímulos perceptivos, isto é, daqueles estímulos oriundos do sistema phi, embora ele não consiga justificar plenamente essa dependência (SIMANKE e CAROPRESO, 2005). No caso dos processos representacionais que se originassem no interior do aparelho - por exemplo, na rememoração -, a consciência dependeria das "associações linguísticas". Freud condiciona a possibilidade de rememoração de uma representação à ligação desta com as associações da linguagem, que constituiriam as representações de pala$v r a$. Ele argumenta que, como a consciência depende do despertar de signos de qualidade e como estes últimos provêm de percepções, para que uma representação ocupada pelo eu (que não provenha de phi) se tornasse consciente seria necessário que, de alguma forma, fosse produzida uma percepção. A solução encontrada é supor que um dos componentes da representação de palavra - a imagem cinestésica da fala - seria capaz de fornecer esse elemento perceptivo: como os movimentos necessariamente originam percepções, a ocupação das imagens de movimento das palavras faladas levaria à produção de um signo de qualidade e, assim, a representação de objeto a ela associada poderia tornar-se consciente.

Freud retoma, pois, no Projeto, os conceitos de representação de palavra (Wortvorstellung) e de representação de objeto (Objektvorstellung) que haviam sido propostos em Sobre a concepção das afasias (FREUD, 1891). A representação de palavra, de acordo com o que havia sido estabelecido nesse último texto, formaria um complexo constituído por um intrincado processo de associações, no qual estariam presentes quatro elementos: a imagem acústica da palavra, a imagem cinestésica da fala, a imagem visual da leitura e a imagem cinestésica da escrita. A representação de objeto seria também um complexo associativo constituído por diversos tipos de imagens sensoriais. A ligação associativa entre esses dois tipos de representações se daria sempre entre a imagem acústica da representação de palavra e, normalmente, a imagem visual da representação de objeto. 
No Projeto, ao se questionar sobre a possibilidade de uma representação ocupada pelo eu tornar-se consciente, Freud retoma esses conceitos. Ele formula a hipótese de que, quando a ocupação de uma representação de objeto seguisse para a imagem acústica da palavra - e, daí, para sua imagem cinestésica -, produzir-se-ia uma percepção que levaria ao despertar de um signo de qualidade, com o que a representação de objeto poderia tornar-se consciente:

(...) se as imagens de recordação forem tais que uma corrente parcial possa ir de uma delas para as imagens acústicas e para as imagens motoras da palavra, então a ocupação das imagens de recordação é acompanhada de notícias de eliminação, que são os signos de qualidade e que, em consequência, também são signos de cons[ciência] da re[cordação] (FREUD, 1895/1950, p. 293).

Dessa forma, com a constituição das representações de palavra, os processos que ocorressem em psi estimulados a partir do interior do aparelho poderiam alcançar a consciência, e não mais apenas aqueles incitados por uma estimulação exógena, surgindo, assim, a possibilidade da rememoração consciente. Portanto, enquanto houvesse apenas representações de objeto no aparelho, os processos representacionais que aí ocorressem seriam inevitavelmente inconscientes, com exceção das percepções e das alucinações. Nestas, a consciência seria imediata, ou seja, decorreria única e diretamente das propriedades das percepções ou dos processos que são tomados por percepções. Com a linguagem, surgiria uma segunda forma de consciência, uma consciência mediata, isto é, intermediada pelos signos linguísticos. ${ }^{6}$

Sendo assim, antes da constituição das associações linguísticas, o pensamento consciente só seria possível se consistisse em uma ação, pois só assim haveria percepções (sensações de movimento) associadas a processos internos - nesse caso, ocupação de representações de movimento. Embora ele não explicite claramente como, a partir de certo momento, o pensamento consciente e a ação poderiam diferenciar-se, é possível inferir que isso se tornaria possível com a constituição das associações da linguagem, as quais permitiram que as ações fossem conscientemente rememoradas e, consequentemente, que não fosse mais imprescindível agir para pensar.

Como vimos, antes da constituição das associações linguísticas, as representações de objeto não teriam nenhuma possibilidade de se tornarem conscientes. Em sua origem - isto é, não ocasião da sua constituição -, elas poderiam ter sido ou não conscientes, o que dependeria de os signos de qualidade por elas despertados terem sido ou não focalizados pelo mecanismo da atenção do eu. No entanto, mesmo se tivessem sido conscientes na ocasião de sua percepção, elas se tornariam, logo em seguida, inconscientes e permaneceriam sem acesso à consciência até que se associassem a palavras. Portanto, a inconsciência seria, teoricamente, o estado originário de pelo menos algumas representações. Já é possível pensarmos, a partir dessas ideias apresentadas por Freud, na possibilidade de parte das representações permanecerem "insuscetíveis de consciência" por não se associarem a representações de palavra. De fato, essa última hipótese é explicitada e desenvolvida no artigo metapsicológico $O$ inconsciente, de 1915.

Em suma, segundo a teoria apresentada no Projeto, o campo da consciência seria mais restrito que o da memória, e apenas uma parte das representações - aquelas capazes de despertar signos de qualidade e que tivessem esses signos ocupados pelo eu - poderia se tornar consciente. A representação é, pois, concebida como um fato de memória, totalmente independente da consciência. Essa última, por sua vez, se define como algo que pode ou não vir a se acrescentar a uma parte das representações, desde que cumpridas certas condições. Antes da constituição das associações linguísticas, a única forma de consciência possível decorreria diretamente das propriedades da percepção - ou seja, seria uma consciência imediata. A constituição das representações de palavra traria consigo a possibilidade de uma segunda forma de consciência, intermediada pelos signos linguísticos. Como uma parte das representações de objeto possivelmente não 
chegaria jamais a ser associada a representações de palavra, poderia haver representações que permanecessem desde sempre insuscetíveis de consciência.

A distinção entre as representações suscetíveis e as insuscetíveis de consciência se limitaria, então, ao fato das primeiras serem representações de objeto associadas a palavras e das últimas serem representações de objeto às quais falta essa associação. Tanto as representações suscetíveis quanto as insuscetíveis de consciência seriam, no funcionamento psíquico normal, governadas pelo processo secundário. ${ }^{7}$ Sendo assim, os processos psíquicos suscetíveis e aqueles insuscetíveis de consciência não possuiriam propriedades intrínsecas diferentes; apenas a presença ou ausência de vínculos com palavras os distinguiria. Portanto, se, no Projeto, encontra-se já a hipótese de um inconsciente dinâmico, constituído por processos inconscientes e psiquicamente ativos, não há ainda nesse texto a concepção do inconsciente como um sistema, a qual só irá começar a tomar forma na Carta 52 (FREUD, 1950) e em A interpretação dos sonhos (FREUD, 1900).

\section{REPRESENTAÇÃO E CONSCIÊNCIA NO CAPÍTULO 7 DE A INTERPRETAÇÃO DOS SONHOS}

O esquema do aparelho psíquico proposto por Freud no capítulo 7 do livro $A$ interpretação dos sonhos (FREUD, 1900) restringe-se a representar a relação dos processos psíquicos com a percepção e a motricidade, além das relações internas entre os sistemas. A relação entre psíquico e somático não está ali representada, apesar de Freud se referir ao papel desempenhado pela excitação de origem endógena no desenvolvimento e no funcionamento do aparelho - sobretudo, na sua conceitualização do desejo que, em linhas gerais, retoma a do Projeto. Portanto, se comparado com o aparelho neuronal de 1895, o aparelho psíquico do capítulo 7 corresponderia somente a phi, psi do manto e ômega. ${ }^{8}$

Freud coloca em um dos extremos do esquema a percepção e, no extremo oposto, a motricidade, e reafirma que o reflexo permanece sendo o modelo elementar de toda a operação psíquica. Os processos psíquicos seriam, inicialmente, regulados automaticamente pelo "princípio de desprazer", zer e desprazer continuam a ser concebidos tal como no Projeto, como sensações conscientes decorrentes, respectivamente, da diminuição e do aumento dos níveis de excitação no aparelho.

A primeira diferenciação estabelecida no aparelho psíquico é entre a percepção e a memória: estas devem ser funções de dois sistemas diferentes, argumenta Freud, devido às mesmas razões já apontadas no Projeto, a saber, as exigências contraditórias e incompatíveis que ambas as funções colocam. Enquanto a percepção requer uma capacidade receptiva sempre igual - e, portanto, o sistema por ela responsável não deve ser modificado de forma permanente pela excitação que recebe -, a memória requer a conservação de traços duradouros - e, portanto, esse sistema deve ser permanentemente modificado pela excitação que o percorre. A percepção fica sendo, então, função do primeiro sistema que compõe o aparelho, e a memória dos sistemas que se lhe sucedem.

A memória não apenas conserva o conteúdo das percepções, como também associa esses conteúdos de acordo com determinadas leis. Para esclarecer o processo da associação, Freud parece retomar as ideias de facilitação e resistência do Projeto, de forma praticamente inalterada. Diz ele: "A associação consiste, então, no seguinte: como consequência de reduções na resistência e de facilitações, desde um dos elementos $M n$ a excitação se propaga melhor em direção a um segundo elemento $M n$ do que em direção a um terceiro" (FREUD, 1900, p. 515). Tudo indica, nessa passagem, que Freud continua a conceber a memória da mesma maneira que no Projeto, isto é, como modificações permanentes resultantes da excitação recebida, as quais se produziriam entre os elementos dos sistemas e não nos próprios elementos, tendo como con- 
sequência a constituição de caminhos preferenciais (uma sequência de "facilitações") para a passagem da excitação. Levando-se isso em conta, pode-se dizer que a representação continua a ser pensada como consistindo em um processo associativo. A seguinte afirmação de Freud corrobora essa interpretação: “(...) representações, pensamentos e produtos psíquicos em geral não podem ser localizados dentro dos elementos orgânicos do sistema nervoso, mas, por assim dizer, entre eles, onde resistências e facilitações constituem seus correlatos" (FREUD, 1900, p. 579). ${ }^{10}$ Em várias ocasiões Freud volta a falar também em neurônios, sugerindo que é mantida a hipótese de que esses seriam os elementos materiais constituintes do aparelho. ${ }^{11}$

Freud retoma aí a ideia que havia sido apontada na Carta 52 como a tese "essencialmente nova de sua teoria": a de que haveria vários sistemas de memória nos quais o mesmo conteúdo estaria transcrito e associado de maneira diferente. De tempos em tempos, esses traços mnêmicos seriam novamente transcritos de acordo com princípios associativos diversos, de forma que a memória seria constituída por vários níveis de registros e se encontraria conservada em sucessivas versões. Na Carta 52, Freud afirmara não saber quantos sistemas deveria haver - no mínimo três, diz ele, provavelmente mais. No esquema do capítulo 7, outros sistemas de memória são incluídos entre o sistema da percepção e o inconsciente. Freud propõe, na seção $B$ desse capítulo, uma representação tópica dos sistemas de memória, que os representa como se eles possuíssem localizações distintas. Adiante, ele esclarece que essa representação tópica é uma representação "auxiliar", empregada com o objetivo de facilitar a explicação dos processos psicológicos.

Nessa mesma seção B do capítulo 7, Freud afirma que os dois últimos sistemas mnêmicos - entre os quais se instalaria uma "censura" - seriam o Inconsciente (Ics) e o Pré-consciente (Pcs). Este último estaria ligado à consciência e governaria o acesso à motricidade voluntária. Esses "sistemas", na verdade, seriam maneiras de representar no modelo do aparelho dois tipos de processos. No início da seção F, Freud afirma:

Se as consideramos com maior atenção, as elucidações psicológicas da seção anterior não nos sugerem a suposição da existência de dois sistemas perto do extremo motor do aparelho, mas sim de dois processos ou de dois modos no decurso da excitação. Para nós dá mesma; sempre devemos estar dispostos a abandonar nossas representações auxiliares quando nos acreditamos em condições de substituí-las por alguma outra coisa que se aproxime mais da realidade desconhecida (FREUD, 1900, p. 578).

Esses dois processos, que corresponderiam aos sistemas pré-consciente e inconsciente, seriam os processos primários e os secundários, que já haviam sido apresentados no Projeto. Portanto, essa diferenciação entre dois "modos no decurso da excitação" seria aquela entre o estado "livre" e estado "ligado" ou "quiescente" (em repouso) da quantidade. O primeiro corresponderia ao processo primário, e o segundo, ao secundário. Apesar da representação dos sistemas como localidades diferentes (a representação tópica) ser uma representação considerada menos rigorosa, pois o que está em questão são processos que se sobrepõem e não processos que ocorrem em lugares distintos, ela deve continuar sendo utilizada, argumenta Freud, uma vez que figura de maneira mais simples e compreensível a distinção pretendida. Assim, a representação tópica deveria continuar sendo usada, nem que fosse apenas por motivos didáticos.

Os sistemas pré-conscientes e inconsciente estabelecem uma diferenciação clara entre os processos suscetíveis e os insuscetíveis de consciência. Os processos secundários (ou seja, o pré-consciente), por incluírem entre suas associações representações de palavra, seriam suscetíveis de se tornarem conscientes. Os processos primários, ao contrário, seriam insuscetíveis de consciência por dois motivos: em primeiro lugar, por permanecerem, ao menos na normalidade, sob inibição do pré-consciente e, portanto, impedidos de acederem à consciência pela via alucinatória; em segundo lugar, por não incluírem representa- 
ções-palavra entre suas associações, o que não lhes permitiria alcançar a consciência pela via normal do pensamento.

No Projeto, como se viu antes, já estava presente a ideia de um psíquico inconsciente e insuscetível de se tornar consciente devido à ausência de vínculos com as representações de palavra. A principal novidade do capítulo 7 em relação a isso parece ser a hipótese de que essas representações inconscientes formariam o conteúdo dos processos primários e, portanto, possuiriam propriedades distintas daquelas do psíquico que têm acesso à consciência (atemporalidade, ausência de contradição, mobilidade das ocupações, substituição da realidade exterior pela psíquica). Para representar essas propriedades distintivas, como Freud esclarece mais tarde, no texto Nota sobre o conceito de inconsciente na psicanálise (FREUD, 1912), é introduzida a concepção dos sistemas inconsciente e pré-consciente. Freud também esclarece, no capítulo 7, que tipo de representações comporia o psíquico insuscetível de consciência: não apenas o reprimido ou seja, representações que foram incorporadas ao sistema pré-consciente, mas acabaram sendo excluídas desse sistema por terem se tornado desprazerosas -, como também moções de desejo que não chegaram a ser incorporadas ao processo secundário, devido ao estabelecimento tardio desse processo, e que, portanto, foram inconscientes desde a origem.

Embora não esteja representada nos esquemas da seção B, Freud diz que a "percepção-consciência" seria a operação psíquica de um sistema particular, ao qual ele atribui a designação abreviada Cs. ${ }^{12}$ Esse sistema se situaria ao lado do Pcs - seria o último sistema, o mais próximo da extremidade motora do aparelho - e suas características mecânicas seriam semelhantes às do sistema de percepção (P): ele apresentaria sempre as mesmas capacidades receptivas, isto é, seria um sistema no qual nenhuma modificação causada pelos processos que aí ocorressem se conservaria permanentemente. Freud define, então, a consciência como "um órgão sensorial para a concepção (Auffassung) de qualidades psíquicas” (FREUD, 1900, p. 578), cuja função seria direcionar a "atenção” que atua no Pcs. Parte da energia de ocupação móvel - isto é, capaz de ser livremente deslocada e empregada em diferentes processos - de que esse último sistema disporia seria usada como "atenção", enquanto outra parte seria usada para inibir e direcionar os demais processos. ${ }^{13}$ Ao dar origem a qualidades, de alguma forma que não nos é explicada, o sistema consciente atrairia a atenção pré-consciente, e esta "sobre-ocuparia" aqueles processos dos quais proviesse a excitação da consciência. Disso decorreria a tomada de consciência de um processo representacional. No Projeto, quem perceberia seria o eu, pois a atenção é uma função que lhe era ali atribuída; agora, no capítulo 7, essa função é transferida ao Pcs, que seria, então, o agente da percepção consciente.

Assim como acontecia no Projeto, uma coisa é um processo despertar qualidade, outra é ele ser, de fato, percebido conscientemente. Para que uma representação fosse de fato conscientemente percebida, seria preciso que a qualidade por ela despertada fosse focalizada pelo mecanismo da atenção. Quanto a isso, Freud esclarece apenas o papel que a consciência exerceria no aparelho e as condições que os processos psíquicos inconscientes teriam que satisfazer para se tornarem aptos a despertar a consciência. O modo de funcionamento do sistema Cs propriamente dito permanece bastante obscuro, como ocorre frequentemente com as formulações sobre a consciência propriamente dita.

Freud prossegue afirmando que "o aparelho psíquico - que, com o órgão sensorial dos sistemas P, está voltado para o mundo exterior - é ele mesmo mundo exterior para o órgão sensorial da Cs, cuja justificação teleológica repousa nessa circunstância” (FREUD, 1900, p. 583). Inicialmente, apenas as excitações provindas de $\mathrm{P}$ e aquelas relacionadas ao prazer e ao desprazer seriam capazes de se tornarem conscientes. Essa excitação proveniente de P teria que passar por um complexo processamento antes de se converter em sensação consciente: ela teria que percorrer toda a extensão do aparelho e passar pelo Pcs, sistema que submeteria todo conteúdo perceptivo a ainda novas elaborações. Portanto, as percepções não despertariam diretamente a consciência, e todo processo que se tornasse consciente teria uma etapa prévia incons- 
ciente. Dessa forma, a consciência continuaria sendo posterior à memória e continuaria sendo concebida como algo que se pode acrescentar ou não a uma representação, dependendo de certas condições. Contudo, Freud argumenta novamente, assim como fizera no Projeto, que a consciência "não é um reflexo supérfluo do processo psíquico consumado" (FREUD, 1900, p. 583).

As sensações de prazer e desprazer, ao direcionarem tanto os processos associativos quanto a percepção dos objetos externos, contribuiriam para a sobrevivência do indivíduo, pois permitiriam a fuga do que lhe representa perigo e a aproximação ao que lhe é benéfico. Esse direcionamento da atenção exercido pela consciência teria, então, uma função imprescindível no desenrolar dos processos psíquicos. Parece ser nesse sentido que se justifica a afirmação de Freud de que a consciência não é um reflexo supérfluo dos demais processos psíquicos: ela desempenharia, em ultima instância, uma função adaptativa. Desde o Projeto, Freud deixara claro que a regulação exercida pelas sensações de prazer e desprazer, assim como a atenção às percepções, seria indispensável à sobrevivência, tanto que, ali, a atenção era definida como a segunda regra biológica, e a regulação dos processos pelas sensações de desprazer, como a primeira regra biológica, ambas atuando desde o início da determinação do funcionamento do aparelho.

Segundo as hipóteses do capítulo 7, as percepções poderiam surgir no aparelho por duas vias distintas: a partir da recepção de excitação de origem exógena ou a partir da ocupação do sistema $\mathrm{P}$ por excitação proveniente do interior do aparelho, isto é, dos sistemas de memória. $\mathrm{O}$ fluxo de excitação que percorreria o aparelho do sistema $\mathrm{P}$ até a via motora é chamado por Freud de "progressivo", e a excitação que o percorreria no sentido inverso - ou seja, dos sistemas de memória ao sistema $\mathrm{P}$ - caminharia, portanto, em sentido "regressivo" - de fato, como se sabe, todo o modelo espacial do aparelho psíquico na seção B do capítulo 7 foi montado, em primeira instância, para dar conta do problema clínico e o teórico da regressão. Na vigília, a excitação em sentido progressivo predominaria, embora também pudesse ocorrer nesse estado fluxos regressivos, pois uma das etapas da rememoração comum consistiria na ocupação regressiva do sistema $\mathrm{P}$, como veremos. No estado de sono, ao contrário, devido ao cessar quase total da corrente progressiva e à redução parcial da atividade inibitória do Pcs - isto próximas à percepção- , o fluxo regressivo se tornaria bem mais intenso e, consequentemente, a ocupação do sistema $\mathrm{P}$ poderia produzir alucinações. ${ }^{14}$

Esse percurso regressivo da excitação teria como resultado a transformação dos pensamentos em imagens sensoriais; ou seja, por meio desse processo, os pensamentos seriam transpostos em percepções e, como toda percepção, seriam capazes de alcançar a consciência e atrair sobre si a atenção pré-consciente. A reativação alucinatória das representações poderia ocorrer também durante a vigília, ou seja, mesmo na presença de um intenso fluxo progressivo de excitação, mas somente em condições patológicas (que Freud define como psicoses). Esses processos regressivos que conduzem à alucinação, tal como ocorre nos sonhos e nas psicoses, restaurariam o modo de atividade primário do aparelho: em primeiro lugar, devido ao seu caráter alucinatório e, em segundo lugar, por submeterem o material representacional aos princípios formais primários, isto é, aqueles vigentes nos primeiros e mais antigos sistemas de memória. Nesse sentido é que Freud diz que a "regressão tópica" é também, ao mesmo tempo, uma "regressão temporal” e uma "regressão formal”. Essa ideia de regressão tópica fora proposta por Breuer nos Estudos sobre a histeria (FREUD; BREUER, 1895) e já se fizera presente também no Projeto, onde Freud propusera que a alucinação resultasse de uma ocupação regressiva do sistema phi a partir de $p s i$.

Desse modo, a consciência, originalmente, consistiria apenas em sensações de prazer e desprazer e em percepções, sendo que estas últimas poderiam surgir no aparelho por dois caminhos distintos (recepção de estímulos externos e alucinações). Freud continua a sustentar a ideia de que, com a associação dos processos psíquicos às palavras, surgiria um novo tipo de consciência, intermediado especificamente pelas associações linguísticas e que, antes da constituição das representações de palavra, os processos psíquicos 
seriam regulados automaticamente pelas sensações de prazer e desprazer. Com a associação desses processos a palavras, eles se tornariam até certo ponto independentes dessa regulação imposta pelas sensações de prazer e desprazer. Ao comentar o papel dos signos linguísticos nos processos associativos, Freud diz explicitamente que é a associação com as representações de palavra que tornaria possível o acesso, por parte da ocupação pré-consciente, a representações desprazerosas, o que aperfeiçoaria o modo de operação do aparelho, pois instauraria uma regulação dos processos mais fina do que aquela do processo primário, exercida apenas pelas sensações de prazer e desprazer.

No entanto, ao contrário do que ocorre no Projeto, Freud não procura especificar no capítulo 7 por que a palavra é capaz de produzir a consciência. Mesmo assim, há uma afirmação na seção B que, somada a uma ideia presente na Carta 52, permite formular uma hipótese a esse respeito. Nessa carta, Freud diz que a consciência do pensamento está ligada à "reanimação alucinatória" da representação de palavra; no capítulo 7, por sua vez, ele afirma que "o recordar intencional e outros processos parciais de nosso pensamento normal correspondem a uma marcha para trás (Ruckschreiten) dentro do aparelho psíquico" (FREUD, 1900, p. 536). De acordo com a teoria do aparelho psíquico que é aí apresentada, pela via regressiva, um pensamento se tornaria percepção, e esse seria o mecanismo responsável pela ativação alucinatória de uma imagem perceptiva. Se o que permite a consciência do pensamento - a rememoração da representação - é sua associação com palavras, e se a rememoração ocorre pela via regressiva, as palavras seriam, nesse processo, transpostas em percepções e, como todas as percepções, poderiam alcançar a consciência e atrair sobre si a atenção. Sendo assim, a consciência do pensamento seria possibilitada pela reativação alucinatória da representação de palavra, como diz Freud na Carta 52. O termo "alucinatório" significaria aí apenas que o processo se daria pelo mesmo caminho da alucinação. Essa reativação da palavra teria que ser pouco intensa para não se confundir com uma nova percepção, ou seja, dar origem a uma alucinação de fato. Em suma, tratar-se-ia de uma reativação alucinatória controlada pelo processo secundário.

No entanto, essa hipótese sobre o mecanismo pelo qual as associações linguísticas poderiam despertar a consciência difere daquela apresentada no Projeto e torna problemático entender por que apenas a palavra possibilitaria a consciência do pensamento. Em 1895, como vimos, Freud havia formulado a hipótese de que a palavra seria capaz de produzir signos de qualidade devido ao seu elemento cinestésico. A ocupação desse último, como todo movimento, produziria uma percepção e, portanto, como qualquer outra percepção, seria capaz de produzir signos de qualidade devido ao seu elemento cinestésico. A ocupação desse último, como todo movimento, produziria uma percepção e, portanto, como qualquer outra percepção, seria capaz de despertar signos de qualidade e atrair sobre si a atenção. Essa hipótese do Projeto é incompatível com a ideia de que é a reanimação alucinatória da palavra que permite a rememoração, pois, no aparelho psíquico do capítulo 7, a percepção produzida pelos movimentos - no caso, pela ocupação da imagem cinestésica da palavra - não se daria pela via regressiva, mas sim pela via progressiva. A ideia de que é por meio da sua ativação alucinatória que a palavra se torna percepção e desperta a consciência parece tornar dispensável também a própria suposição de que só a palavra seria capaz de fazê-lo. Não parece haver, em princípio, nenhum impedimento para que uma imagem visual, por exemplo, se tornasse consciente a partir desse mesmo processo. Nos artigos metapsicológicos de 1915, Freud levanta, ele mesmo, essa questão, a qual é retomada em $O$ eu e o isso (1923), como veremos adiante.

Uma vez que a percepção só alcançaria a consciência após passar por todos os sistemas que separam os dois extremos do aparelho, podemos dizer que a informação sensorial exógena só se tornaria consciente após passar por um longo processamento e por sucessivas reorganizações. A rememoração teria uma primeira etapa regressiva (do Pcs a $\mathrm{P}$ ), na qual as palavras seriam transpostas em percepções, e uma segunda etapa progressiva (de $\mathrm{P}$ a Cs), por meio da qual a percepção se tornaria consciente. Assim, a percepção ordinária - isto é, aquela produzida pela recepção de estímulos exógenos - se daria por um processo pro- 
gressivo, e a rememoração possuiria duas etapas: uma regressiva e outra progressiva, da mesma forma que a alucinação. A diferença entre a rememoração e a alucinação seria apenas quantitativa ou de intensidade, uma concepção que já vem dos primeiros trabalhos de Freud sobre a histeria e as neuroses (SIMANKE, 2009).

No capítulo 7 de $A$ interpretação dos sonhos, Freud sugere a existência de uma censura entre os sistemas Cs e Pcs, semelhante àquela que haveria entre este último sistema e o Ics. Ele afirma o seguinte com referência ao sistema pré-consciente: "suas excitações - certamente obedecendo também a certas regras e, talvez, só depois de superar uma nova censura, mas sem consideração pelo sistema Ics - podem alcançar a consciência” (FREUD, 1900, p. 582). Essa censura entraria em ação acima de certo limite quantitativo, de modo que pensamentos de pouca intensidade se subtrairiam à sua ação. Com essa hipótese, o autor parece estar supondo que, mesmo entre os processos que envolvessem palavras, haveria alguns que não se poderiam tornar conscientes devido a sua baixa intensidade e outros que seriam barrados pela censura entre Pcs e Cs, o que, de certa forma, implica que haveria um "insuscetível de consciência" dentro do pré-consciente. Dois fatores fariam com que um processo pré-consciente fosse capaz de despertar a consciência: estar associado a palavras e possuir uma intensidade acima de certo limiar. No entanto, esses processos "capazes de despertarem a consciência" só a despertariam de fato se não fossem barrados pela censura existente entre o Pcs e o Cs. Sendo assim, com exceção das percepções e das sensações de prazer e desprazer, apenas aqueles processos que estivessem associados a palavras, que possuíssem certa intensidade e que não fossem barrados pela censura poderiam se tornar conscientes. No artigo $O$ inconsciente, Freud retoma essa hipótese da existência de uma censura entre Pcs e $\mathrm{Cs}^{15}$ e no artigo metapsicológico $A$ repressão, ele esclarece que seriam justamente os derivados do reprimido que estariam submetidos a essa censura (CAROPRESO, 2009).

\section{CONSCIÊNCIA, LINGUAGEM E PERCEPÇÃO NOS ARTIGOS METAPSICOLÓGICOS}

Nos artigos metapsicológicos (1917-1917), inicialmente, Freud hesita em distinguir entre os sistemas pré-consciente $(P c s)$ e consciente (Cs) e em considerá-los como duas instâncias distintas. Em $O$ inconsciente (1915), ele afirma que um ato psíquico em geral passaria por duas fases, entre as quais operaria como seletor um tipo de exame ou censura. Na primeira fase, tal ato seria inconsciente e pertenceria a esse sistema. Se não fosse rechaçado pela censura, ele passaria para a segunda fase, sendo integrado ao sistema Cs; mas, caso fosse recusado pela censura, permaneceria como reprimido no Ics. No primeiro caso, o processo psíquico não seria ainda consciente, mas apenas "suscetível de consciência”, isto é, poderia ser objeto da consciência sempre que se apresentassem certas condições adicionais. Devido a essa suscetibilidade de consciência, diz ele, chamamos ao sistema da consciência também de "pré-consciente". Freud, nesse ponto, apresenta então, claramente, sua dúvida quanto a diferenciar ou não os sistemas Pcs e Cs:

Caso se chegasse a averiguar que o tornar-se consciente do pré-consciente é, por sua vez, codeterminado por certa censura, deveríamos isolar entre si com rigor os sistemas Pcs e Cs. Provisoriamente basta estabelecer que o sistema Pcs participa das propriedades do Cs, e que a censura rigorosa está em função na passagem do Ics ao Pcs (ou Cs) (FREUD, 1915a, p. 132).

Adiante, nesse mesmo artigo, Freud conclui que, de fato, é preciso supor a presença de uma censura também entre Pcs e Cs, ou seja, que os processo suscetíveis de consciência (os pré-conscientes) têm que superar uma censura para se tornarem efetivamente conscientes. Mas, apesar de, já no artigo sobre o inconsciente, Freud reconhecer que é preciso supor a presença dessa censura atuando sobre os processos pré-conscientes - a qual decidira sobre o tornar-se consciente e implicaria distinguir os sistemas Pcs e 
Cs -, ele continua se referindo a esses dois sistemas indistintamente. Ele ainda se refere ao sistema "Pcs (Cs)" ou "Cs (Pcs)". Somente a partir do texto "Complementos metapsicológicos à teoria dos sonhos" (1917), o penúltimo dos artigos metapsicológicos a ser escrito, ele passa a diferenciar, de fato, entre os dois sistemas.

Nesse último texto, ele reconhece que até então não havia separado claramente os dois sistemas e que é preciso, agora, fazê-lo. Ao passar a tratar o sistema Cs como um sistema independente do pré-consciente, Freud passa a se referir ao sistema $C s(P)$ - ou seja, como um sistema de percepção-consciência. Não fica claro, no entanto, se ele está identificando os dois sistemas - isto é, se Cs e P seriam o mesmo sistema - ou se ambos estariam apenas ligados. De qualquer forma, há uma nítida modificação em relação ao que é proposto no capítulo 7. Lá o sistema $\mathrm{P}$ e o sistema Cs localizavam-se em cada uma das extremidades opostas do aparelho. Agora, Freud passa a se referir a eles como se fossem um único sistema ou, então, como se fossem dois sistemas próximos e ligados. Mas, onde, no aparelho, esse sistema Cs (P) estaria situado? No lugar correspondente a $\mathrm{P}$ na tópica do capítulo 7 ou na extremidade oposta, correspondente a Cs? Ou ambas extremidades estariam, de alguma forma, ligadas, de forma que Cs (P) estaria conectado tanto ao sistema Ics quanto ao sistema Pcs? Esta última hipótese parece ser a mais frutífera para a teoria, mas Freud não se define quanto a essa questão.

Em uma nota agregada em 1919 ao capítulo 7, ele diz: "A posterior ampliação desse esquema de desenvolvimento linear deverá incluir a suposição de que o sistema que segue ao Pcs é aquele ao qual temos que atribuir a consciência, vale dizer, $\mathrm{P}=\mathrm{Cs}$ " (FREUD, 1900, p. 5350). Nessa passagem, Freud parece estar propondo a junção das duas extremidades do aparelho para fazer coincidirem os dois sistemas; no entanto, nos artigos metapsicológicos, isso ainda não fica claro. Sabemos, contudo, que o sistema Cs (P) tem que estar ligado ao Pcs, pois foi justamente a existência de uma censura entre ambos que levou Freud a distingui-los. Portanto, a primeira alternativa pode ser descartada.

Freud é bastante ambíguo nos artigos metapsicológicos quanto à localização do sistema P. Ele, às vezes, o situa ao lado do Pcs-Cs, propondo que a atividade psíquica siga dois circuitos opostos: um que parte dos estímulos externos e segue pelo Pcs-Cs até chegar ao sistema Ics, e outro que parte das pulsões e alcança o Cs por intermédio do Ics. Em outras ocasiões, ele situa P ao lado do sistema Ics, como acontece no capítulo 7, e sustenta que os estímulos externos alcançariam P, seguiriam pelo Ics, pelo Pcs e, enfim, alcançariam o sistema Cs. A identificação entre Cs e $\mathrm{P}$ e a união dos dois polos do aparelho resolveriam a questão da localização de $\mathrm{P}$, pois colocariam esse sistema em ligação tanto com os sistemas consciente $\mathrm{e}$ pré-consciente quanto com o inconsciente. Contudo, o percurso da excitação pelos sistemas continuaria indefinido, assim como a relação entre consciência e percepção. Esta última se tornaria consciente de forma imediata, uma vez que $\mathrm{P}$ e Cs seriam um só sistema ou estariam intimamente ligados? Mas, nesse caso, a consciência precederia a constituição da representação? Parece não ser essa a hipótese com que Freud está trabalhando, pois um pouco antes de estabelecer a separação entre Pcs e o sistema Cs e de associar este último a P no Complemento metapsicologia à teoria dos sonhos, Freud volta a afirma, como no capítulo 7, que todo conteúdo perceptivo seria submetido à elaboração secundária antes de se tornar consciente, o que implicaria que a excitação proveniente do mundo externo, antes de alcançar Cs, passe pelo Ics e pelo Pcs. Essa hipótese poderia se conciliada com a união das duas extremidades do aparelho, pois $\mathrm{P}$ estaria ligado ao Ics, e o percurso da excitação, no caso das percepções, poderia continuar sendo o mesmo proposto no capítulo 7, isto é, P - Ics - Pcs - Cs. Só que isso só seria possível se os sistemas P e Cs não estivessem sendo identificados de fato, uma vez que essa identificação implicaria que as percepções se tornassem conscientes imediatamente, sem serem previamente elaboradas. Se essa fosse a hipótese sustentada por Freud - de que P e Cs não são o mesmo sistema, mas apenas estão em conexão próxima e 
que o percurso da excitação continua sendo o mesmo do capítulo 7 -, algumas modificações teriam que ser introduzidas no modo de conceber a formação do sonho e a rememoração.

Contudo, a ambiguidade de Freud quanto à relação entre percepção e os processos psíquicos não nos permite concluir nada de definitivo a respeito da relação entre esses dois processos - a consciência e a percepção. Ao contrário do que faz a respeito dos sistemas Pcs e Ics, Freud não esclarece quais seriam as características distintivas do sistema $\mathrm{Cs}(\mathrm{P})$. A relação entre a representação e a consciência torna-se, nos artigos metapsicológicos, muito mais obscura do que no Projeto e no capítulo 7, provavelmente porque Freud pretendia publicar outro artigo que trataria exclusivamente da consciência, no qual essas questões poderiam ser desenvolvidas com maiores detalhes. Esse artigo, no entanto, foi descartado por ele, de modo que a concepção freudiana sobre a consciência, nesse momento, por mais insatisfatória que lhe tenha parecido, só pode ser parcialmente reconstruída a partir dessas menções esparsas nos trabalhos metapsicológicos efetivamente publicados.

Ao contrário do que ocorre no Projeto, no capítulo 7, Freud, como vimos, não especificara qual seria o mecanismo pelo qual as representações de palavra possibilitariam a consciência; no entanto, ele afirma que a rememoração comum consiste em um processo regressivo. Na Carta 52, ele havia sustentado que a consciência do pensamento resultaria da reanimação alucinatória da palavra. Uma vez que a reativação alucinatória das representações é pensada, no capítulo 7, como consistindo em um processo regressivo, do Pcs a P, e que seria a palavra que possibilitaria a rememoração, tudo indica que a reativação alucinatória das palavras seria o mecanismo pelo qual o pensamento poder-se-ia tornar consciente.

Mas, nesse caso, como argumentamos anteriormente, não seria possível compreender por que a consciência do pensamento dependeria da palavra, uma vez que as representações de coisa - como, exemplarmente, acontece no sonho - poderiam também ser transpostas em percepções. Nos artigos metapsicológicos, Freud levanta explicitamente essa questão. Ele diz:

As representações de palavra provêm, por sua parte, da percepção sensorial da mesma maneira que as representações de coisa, de modo que poderíamos colocar essa pergunta: por que as representações de objeto não se podem tornar conscientes por meio de seus próprios restos de percepção? (FREUD, 1915a, p. 160).

A sua resposta é a seguinte:

É que provavelmente o pensar se desenvolve dentro de sistemas tão distanciados dos restos de percepção originários que nada conservaram de suas qualidades e, para se tornarem conscientes, necessitam de um reforço de qualidades novas. Além disso, mediante o enlace com palavras, podem ser providas de qualidade mesmo aquelas ocupações que não puderam levar consigo qualidade alguma das percepções porque correspondiam a meras relações entre as representações de objeto (FREUD, 1915a, p. 160).

Freud reconhece, então, que a hipótese de que a palavra permite a consciência ao ser transposta em percepção deixa em aberto a questão de por que as representações de coisa não se poderiam tornar conscientes sem o seu auxílio, visto que também poderiam ser transpostas em percepções, como ocorre na alucinação. Além disso, é preciso reconhecer que há coisas no psíquico que se tornam conscientes mesmo sem nunca terem sido percepções, como as relações entre as percepções. Isso implica que deveria haver alguma propriedade exclusiva das palavras que justificasse a dependência da rememoração em relação a elas; dito de outro modo, que deveria haver alguma propriedade exclusiva da palavra que a tornasse capaz de produzir qualidades e de atribuir qualidades mesmo naquilo que nunca foi percepção. Freud não apresenta, no entanto, nenhuma sugestão sobre qual poderia ser essa propriedade exclusiva das palavras. Cabe notar que a hipótese do Projeto - de que o elemento cinestésico da palavra é que possibilitaria a 
consciência por produzir novas percepções no aparelho - era muito menos problemática que sua hipótese posterior, pois atribuía a uma característica exclusiva das representações de palavra a capacidade de fazer surgir a qualidade nos processos do aparelho. Na verdade, essa hipótese do Projeto parecia resolver satisfatoriamente a questão. No entanto, nos artigos metapsicológicos, Freud não volta a se referir a ela: ele continua, nesses artigos, concebendo a possibilidade de rememoração de uma representação como sendo dependente da associação com representações de palavra, mas parece não possuir uma hipótese definida sobre como e por que isso se daria.

Dentro de todo esse contexto, Pcs e Cs passam a ser considerados como dois sistemas diferentes. Sabemos que o Pcs corresponde aos processos secundários e que esses processos são suscetíveis de se tornarem conscientes devido ao seu vínculo com as representações de palavra. Assim como no capítulo 7, não bastaria estar associado à palavra - isto é, pertencer ao processo secundário - para, de fato, despertar a consciência. A representação de palavra tornaria os processos suscetíveis de consciência, mas seria necessário vencer uma censura para que algo se tornasse, de fato, consciente. Parte do conteúdo do Pcs estaria submetida a essa censura, a saber, aquele setor que consiste em derivados do reprimido primordial. $\mathrm{O}$ restante do conteúdo Pcs seria suscetível de consciência sem censura.

Freud restringe, então, em 1915, a ação da censura, se comparada com a concepção apresentada em 1900 - só os derivados do reprimido estariam a ela submetidos. Esses derivados do inconsciente poderiam ou não sucumbir à repressão propriamente dita; aqueles que escapassem à repressão permaneceriam ainda submetidos à censura situada entre Pcs e Cs e dela dependeria sua capacidade de se tornarem ou não conscientes. Vimos que, já no capítulo 7 , Freud havia mencionado a existência de uma censura entre os sistemas Pcs e Cs, a qual, segundo ele, atuaria sobre processos com intensidade que ultrapassasse certo limite; acima desse limite, os processos pré-conscientes não poderiam se tornar conscientes. Sobre a relação entre a censura e a intensidade dos processos, Freud afirma, nos artigos metapsicológicos, que aqueles derivados do inconsciente que superassem certa intensidade sucumbiriam à repressão, pois, caso contrário, conseguiriam impor-se à Cs. Esta afirmação nos sugere duas coisas: primeiro, que o que se torna alvo da repressão propriamente dita é aquele processo derivado do reprimido primordial que atinge certa intensidade; segundo, que a intensidade do processo pré-consciente, de alguma forma, está relacionada com o tornar-se consciente. No entanto, processos muito intensos necessariamente se imporiam à consciência; a censura seria incapaz de contê-los.

Freud volta a se referir ao mecanismo da "atenção" nos artigos metapsicológicos. Na seguinte passagem de $O$ inconsciente, ele parece propor que haveria uma relação entre o mecanismo da atenção e a censura entre o sistema Pcs e Cs: “(...) muito do que participa das propriedades do sistema Pcs não se torna consciente; $e$, todavia, chegaremos a saber que certas orientações da atenção deste sistema são restritivas do tornar-se consciente" (FREUD, 1915a, p. 151).

Essa afirmação de Freud dá a entender que o que seria censurado na barreira entre o Pcs e o Cs seria aquilo que não fosse alvo da atenção, e a afirmação que se segue sugere que a atenção continua sendo concebida de forma muito próxima ao Projeto: "(...) a existência da censura entre Pcs e Cs nos adverte que o tornar-se consciente não é um mero ato de percepção, mas que provavelmente se trata também de uma sobreocupação, um progresso posterior da organização psíquica" (FREUD, 1915a, p. 152).

No Projeto, o mecanismo da atenção era pensado como uma sobreocupação dos signos de qualidade que se constituiriam no sistema psi. Para que uma representação se tornasse consciente, não bastaria que ela despertasse os signos de qualidade: seria necessário, ainda, que esses signos fossem focalizados pelo mecanismo da atenção. 
As afirmações anteriores sugerem que Freud continua concebendo a relação entre a representação e a consciência de forma muito semelhante em 1915. As representações pré-conscientes censuradas seriam aquelas que, embora possuam todos os requisitos necessários para se tornarem conscientes, não foram focalizadas pela atenção. Dessa forma, Freud teria mantido a hipótese de que o tornar-se consciente depende, entre outras coisas, da focalização das representações pelo mecanismo da atenção, o qual continua, então, a desempenhar um papel fundamental nesse processo.

\section{A SEGUNDA TÓPICA FREUDIANA E A FORMA FINAL DO PROBLEMA}

Em Além do princípio do prazer (1920), o problema da relação entre a percepção e a consciência, que havia permanecido indefinido nos artigos metapsicológicos, ganha maior precisão: Freud continua falando em um sistema P-Cs e parece abandonar definitivamente a ideia de que a excitação oriunda do mundo externo incidiria sobre o Ics, passaria pelo Pcs e, só então, chegaria ao sistema consciente. Os sistemas $\mathrm{P}$ e Cs, de fato, deixam de ser diferenciados: tratar-se-ia de um único sistema que receberia a excitação exógena diretamente. Freud formula, então, a hipótese de que esse sistema permanece sempre igualmente receptivo - isto é, não é modificado pela excitação que o percorre -, devido a sua localização, isto é, ao fato de estar em contato direto com a excitação proveniente do mundo externo:

O sistema Cs se singularizaria, então, pela particularidade de que nele, diferentemente do que ocorre em todos os outros sistemas psíquicos, o processo de excitação não deixa atrás de si uma alteração permanente de seus elementos, mas esgota, por assim dizer, no fenômeno do tornar-se consciente. Semelhante desvio da regra geral deve ser explicado por um fator que seja exclusivo deste sistema; bem, esse fator, que falta a todos os outros sistemas, poderia ser a situação do sistema Cs que acabamos de expor: seu choque direto com o mundo exterior (FREUD, 1920. p. 235).

Freud propõe, então, que a excitação exógena se choque, em primeiro lugar, com o sistema Cs; depois, ela seguiria para os sistemas de memória. Ele afirma que, no sistema Cs, o processo excitatório se tornaria consciente, mas não deixaria como sequela traços permanentes, os quais se formariam somente nos sistemas de memória contíguos a ele. A permeabilidade que caracterizaria a consciência é uma hipótese antiga na teoria; a novidade que aparece nesse momento é o fato de primeiro algo se tornar consciente e só depois vir a ser representado.

Freud tenta relacionar a permeabilidade que caracterizaria a consciência com sua localização, isto é, com o fato do sistema por ela responsável ser atingido diretamente pelas excitações do mundo externo. Algumas hipóteses a respeito de como um sistema desse tipo poderia ter se constituído são, então, formuladas. Apoiando-se no conhecimento fornecido pela embriologia de que o sistema nervoso central teria provindo da ectoderme, ele passa a especular a respeito da origem do sistema consciente. Um organismo vivo primitivo, que consistisse em uma vesícula indiferenciada de substância estimulável, com a recepção continua de estimulação, acabaria tendo sua superfície externa diferenciada até um ponto em que não pudessem ocorrer mais modificações, de forma que essa superfície acabaria se tornando totalmente permeável à excitação. Dessa forma, teriam sido criadas as condições para que surgisse a consciência:

Dessa forma, ao final, do processo, haveria se formado um córtex tão crivado pela ação dos estímulos, que ofereceria as condições mais favoráveis para a recepção destes e já não seria suscetível de posterior modificação. Transpondo ao sistema Cs, isso significaria que a passagem da excitação já não poderia imprimir nenhuma alteração permanente em seus elementos. Eles estariam modificados ao máximo no sentido deste efeito, ficando então habilitados para gerar consciência (FREUD, 1920, p. 236). 
A camada mais externa poderia, mesmo, ter-se tornado inorgânica ou quase inorgânica, passando a funcionar, então, como uma superfície protetora, que barraria ao menos uma parte dos estímulos. Com isso, ter-se-ia estabelecido uma camada mais externa, que filtraria a estimulação, e uma camada imediatamente contígua, totalmente permeável aos estímulos. Os processos dos estratos mais profundos da vesícula passariam, com isso, a transcorrer de maneira diferente; neles, os estímulos deixariam atrás de si modificações permanentes. Freud retoma, então, em Além do princípio do prazer, praticamente as mesmas hipóteses do Projeto, para explicar em que consistiriam essas modificações permanentes:

Em que consistiu essa modificação da substância e do processo excitatório que decorre dentro dela? (...) Uma suposição possível seria que, em seu avanço de um elemento ao outro, a excitação tem que vencer certa resistência e, justamente, a redução desta cria o traço permanente da excitação (facilitação); poder-se-ia pensar, então, que no sistema Cs já não subsiste nenhuma resistência de passagem dessa índole entre um elemento e outro (FREUD, 1920, p. 236).

Nos organismos superiores, especula Freud, o estrato cortical da antiga vesícula, que recebia os estímulos, teria sido internalizado no corpo e deixado atrás de si, na superfície, os órgãos sensoriais. Na segunda sessão de O ego e o id (1923), Freud retoma essa hipótese, já apresentada em Além do princípio do prazer, de que a consciência estaria na superfície do aparelho psíquico: sobre ela incidiriam diretamente os estímulos provenientes do mundo externo. Mas, além das percepções externas, as sensações e os sentimentos - isto é, os processos que se originam no interior do corpo - também se tornariam conscientes. A consciência dos estímulos externos, assim como aquela das sensações provenientes do interior do corpo, seria, de certa forma, "imediata", ou seja, não dependeria da intermediação de outros fatores. Mas, e o pensamento? Como já vimos, a resposta de Freud, desde o Projeto, é que o pensamento se torna consciente por intermediação das palavras. Freud retoma mais uma vez, em 1923, essa hipótese, mas agora ele admite que o pensamento com palavras não é a única forma de pensamento consciente: poderia haver pensamentos que se tornam conscientes a partir apenas da ativação de imagens visuais.

As seguintes questões são, então, levantadas. São os pensamentos que vêm à superfície, consumando-se em algum lugar do interior do aparelho com deslocamentos de energia psíquica, que fazem então surgir consciência? Ou é a consciência que, de alguma maneira, vai até eles? Em outras palavras, para ser tornar consciente, o processo de pensamento deve se dirigir à superfície, onde se localiza a consciência, ou seria essa superfície que iria até o processo de pensamento? A resposta de Freud é: nem uma coisa nem outra. Ele retoma, então, as hipóteses que haviam sido explicitadas nos artigos metapsicológicos de 1915. Para algo se tornar pré-consciente - lembremos que, agora, isso quer dizer apenas "suscetível de consciência", pois Freud abandona em 1923 a hipótese dos sistemas pré-consciente e inconsciente -, é preciso que adquira uma conexão com representações de palavra. Nesse sentido, a diferença entre um processo suscetível e um processo insuscetível de consciência é que o primeiro está associado a representações de palavra e o segundo, não. Mas, como as palavras tornariam possível a consciência? Em O ego e o id, Freud volta a afirmar que a palavra produziria qualidades sensoriais ao ser novamente transposta em percepção. Mas, nesse momento, ele expande sua concepção a respeito da possibilidade de consciência do pensamento. Tudo aquilo que um dia foi percepção, diz ele, pode tornar-se novamente consciente:

Essas representações de palavra são restos mnêmicos; uma vez foram percepções e, como todos os restos mnêmicos, podem se tornar de novo conscientes (...); com exceção dos sentimentos, o que a partir de dentro quer se tornar consciente tem que tentar se transpor em percepções exteriores. Isto se torna possível por meio dos traços mnêmicos (FREUD, 1923, p. 289)

O pensamento não dependeria mais, então, exclusivamente das representações de palavra para se tornar consciente: haveria processos de pensamento que se tornariam conscientes a partir da reativação de 
imagens visuais, por exemplo. Esse pensamento visual, característico do sonho, é um tipo de pensamento mais arcaico, tanto ontogenética quanto filogeneticamente. Trata-se, diz Freud, de um tornar-se consciente muito imperfeito. A consciência dependeria de que um traço mnêmico fosse transposto em percepção, o que parece consistir em uma ocupação regressiva dos sistemas de memória até o sistema responsável pela consciência. Uma regressão desse tipo, dependendo de sua intensidade menor ou maior, teria como consequência, respectivamente, uma simples rememoração ou uma alucinação. Entre a alucinação e a rememoração ordinária, haveria apenas uma diferença de intensidade, não de natureza. Essa hipótese que, na verdade, já se insinuava desde o capítulo 7 - pois Freud sugere aí que rememoração consistiria em um processo regressivo -, é apresentada da forma mais explícita em $O$ ego e o id.

Embora o pensar com palavras não seja a única forma de pensamento consciente, ele seria uma forma de pensamento mais evoluída: as palavras permitiriam que o pensamento se libertasse das imagens concretas. No Projeto, Freud afirmara que o pensamento, na origem, consistiria na reativação de imagens de movimento; inicialmente, pensar seria, de alguma forma, mover-se ou esboçar movimentos. A partir de determinado momento, o pensamento se tornaria independente da ação. Podemos, com as hipóteses introduzidas em 1923, acrescentar que, além do pensamento que consistiria em ação, haveria outra forma de pensamento primitiva, que se daria a partir da reativação de imagens visuais, o que talvez já correspondesse a um nível um pouco mais desenvolvido de pensamento. Assim, primeiro o pensamento seria ação; depois, reativação de imagens visuais; e, por último, reativação de palavras. Este último seria, provavelmente, a marca distintiva do homem perante os outros animais. Freud mantém, no entanto, a hipótese de que o que tornaria uma representação pré-consciente seria sua ligação com palavras, e que tornar consciente algo inconsciente dependeria do restabelecimento do vínculo perdido ou inexistente com as palavras. No artigo metapsicológicos sobre o inconsciente de 1915, ao se perguntar por que as representações de objeto precisam de palavras para se tornarem conscientes, Freud respondera que provavelmente o pensar se desenvolveu em sistemas tão distantes dos restos de percepção originários que nada conservaram de suas qualidades, de forma que, para se tornarem conscientes, necessitariam de um reforço de qualidades novas. Poderíamos pensar que, embora o pensamento não dependesse exclusivamente das palavras, estas o assegurariam e o aperfeiçoariam. O fato é que, embora Freud reconheça que a palavra não é o único fator por meio do qual algo pode ser rememorado, ele continua vinculando o estado de pré-consciência - e, portanto, a suscetibilidade à consciência - às representações de palavra. Esta contradição permanece, assim, insolúvel.

Freud conclui, então, que tanto os processos correspondentes ao pensamento quanto os que correspondem às sensações corporais teriam que alcançar o sistema P-Cs para se tornarem conscientes, mas as representações do pensar só poderiam atingir esse sistema a partir da intermediação das palavras, enquanto as sensações corporais o fariam diretamente. Por isso, ele afirma que uma representação do pensamento pode ser consciente, pré-consciente ou inconsciente. Já para as sensações, esta segunda possibilidade estaria excluída: elas só poderiam ser inconscientes ou conscientes. A representação pré-consciente continua sendo pensada como aquela associada à palavra, e a inconsciente como a que não se encontra assim associada.

Em relação à consciência, a principal mudança que surge em Além do princípio do prazer e em O ego e o id é, em primeiro lugar, a explicitação da identificação entre os sistemas P e Cs. Não há mais, como no Projeto e no capítulo 7 do livro sobre os sonhos, um sistema responsável pela recepção da excitação exógena e outro responsável pela consciência: ambas as funções passam a ser desempenhadas pelo mesmo sistema, o qual agora é denominado "P-Cs" ou apenas "Cs". Como consequência dessa identificação, surge uma mudança importante na forma como a relação entre a consciência e a representação é pensada. No Projeto e no capítulo 7, assim como em algumas passagens dos artigos metapsicológicos, Freud considerava que a 
excitação proveniente do mundo externo incidiria sobre um primeiro sistema ( $p h i$ ou P), daí seguiria para os sistemas de memória ( $p s i$ ou Pcs e Ics), para só então chegar ao sistema responsável pela consciência (ômega ou Cs). Portanto, tratava-se de uma hipótese segundo a qual, primeiro, ocorreria o processo de constituição da representação e, depois, o despertar da consciência, que seria, assim, sempre algo posterior à constituição da representação. Uma representação se formaria e, mesmo que correspondesse a uma representação de algo externo, poderia ou não vir a se tornar consciente. No capítulo 7, Freud diz que todo conteúdo, antes de ser consciente, sofre o processo da elaboração secundária e que essa elaboração se daria na passagem da excitação pelos sistemas Ics e Pcs. Portanto, até então, havia sido estabelecido que a formação dos traços de memória precederia a consciência.

Com a identificação entre os sistemas $\mathrm{P}$ e Cs e com a localização desse sistema na superfície do aparelho, a relação entre representação e consciência tem que ser pensada de forma distinta, embora Freud não chegue a discutir detalhadamente essa questão. Se a excitação proveniente do mundo externo incidir diretamente sobre a superfície responsável pela consciência, para, em seguida, chegar aos sistemas de memória, isso parece implicar que a percepção torne-se consciente antes de ser representada, isto é, antes da constituição dos traços de memória. Desse modo, em relação às percepções oriundas do mundo externo, desapareceria a antiga hipótese de que a memória precederia a consciência. Quanto às representações constituídas a partir da excitação endógena, continuaria valendo a hipótese anterior de que elas teriam que percorrer os sistemas de memória antes de se tornarem conscientes.

Mas, se as percepções externas se tornassem primeiro conscientes para depois serem representadas ou seja, se o processo de elaboração secundária não mais antecedesse a consciência de uma percepção -, isso implicaria que nossas percepções e nossas representações seriam pensadas como sendo uma cópia fiel dos estímulos externos, como correspondendo ponto a ponto aos estímulos que incidissem sobre a periferia do sistema nervoso? Não parece possível tirar essa conclusão, se lembrarmos das ideias formuladas por Freud em Sobre a concepção das afasias (CAROPRESO, 2008). Nesse texto, Freud defendera que, no processo de condução dos estímulos externos da medula ao córtex, esses estímulos passariam por sucessivos rearranjos, de forma que, entre aquilo que tivesse partido da periferia e aquilo que chegasse ao córtex, haveria uma relação bastante indireta (CAROPRESO, 2008a). Tendo isto em vista, podemos concluir que, mesmo se aquela informação que chegasse ao córtex cerebral se tornasse imediatamente consciente, ainda assim não seria possível dizer que o que se torna consciente seria uma cópia fiel daquilo que ingressou no sistema nervoso. Portanto, de qualquer maneira, teria sido mantida a hipótese proposta em sobre a concepção das afasias de que nossas percepções e nossas representações consistiriam no resultado conjunto de uma forma determinada pelo sistema nervoso e de um conteúdo adquirido através da experiência.

Essa precedência da percepção em relação à memória parece abrir a possibilidade de que a memória reorganize as percepções, uma vez que a representação consiste em um processo associativo que ocorre após a percepção. Isso teria como consequência que a rememoração de algo nunca fosse exatamente igual a sua percepção. Outra questão que podemos levantar é se estaria implicada nas ideias definidas por Freud nesse momento que toda percepção - ou seja, todo material proveniente do mundo externo - seria necessariamente percebida conscientemente. Mais uma vez, a resposta parece ser não, e podemos justificá-la a partir das ideias do Projeto, as quais são retomadas no capítulo 7. Nesses dois textos, Freud diferencia o surgimento de qualidades sensoriais - que resultaria da operação do sistema Cs - do fato de algo ser percebido conscientemente. Para algo ser conscientemente percebido, seria preciso que o mecanismo da atenção do ego (Projeto) ou do Pcs (capítulo 7 e artigos metapsicológicos) focalizasse os signos de qualidade produzidos pelo sistema responsável pela consciência. 
Portanto, haveria a possibilidade de que as percepções, mesmo que produzindo qualidade, não fossem de fato percebidas. Essa relação entre a atenção e o surgimento da qualidade sensorial pode ser pensada mais ou menos da mesma forma, apesar da modificação da relação entre a percepção e a consciência ocorrida em 1923. Em Nota sobre o bloco mágico (1925), embora não fale explicitamente em um mecanismo da atenção, Freud dá indicações de que essa hipótese ou algo muito semelhante continua sendo pressuposto na teoria:

Tenho suposto que inervações de ocupação são enviadas e recolhidas novamente em golpes periódicos rápidos desde o interior até o sistema P-Cs, que é completamente permeável. Enquanto o sistema permanece ocupado desse modo, recebe as percepções acompanhadas de consciência e transmite a excitação até os sistemas mnêmicos inconscientes; assim que a ocupação é retirada, a consciência se extingue, e a operação do sistema é suspensa. Seria como se o inconsciente, por meio do sistema P-Cs, estendesse ao encontro do mundo exterior umas antenas e as retirasse rapidamente depois que estas tiraram amostras de suas excitações (FREUD, 1925b, p. 369).

A consciência de uma percepção continuaria, assim, dependendo de que algo produzido no sistema P-Cs fosse alvo de uma ocupação que parte do interior do aparelho, isto é, continuaria havendo algo como um mecanismo da "atenção", pressuposto na teoria desde os seus primórdios. Portanto, apesar da união dos sistemas $\mathrm{P}$ e Cs, a hipótese de que o surgimento de qualidades sensoriais não implica necessariamente a consciência dessas qualidades parece estar sendo mantida.

\section{CONSIDERAÇÕES FINAIS}

Tanto no Projeto como no capítulo 7 de $A$ interpretação dos sonhos, a representação é pensada como um fato de memória, ao qual, a consciência pode ou não vir a se acrescentar. Em ambos os textos, Freud postula um sistema diferenciado que seria especificamente responsável pela produção de qualidades sensoriais. Estas últimas seriam condição necessária para que uma representação viesse a ser conscientemente percebida, mas elas não seriam condição suficiente, uma vez que, para isso, seria necessária a sua focalização pelo mecanismo da "atenção". Este, por sua vez, é pensado como uma função do eu no Projeto e como uma função do pré-consciente no capítulo 7 e nos artigos metapsicológicos. Já no Projeto, Freud reconhecia que a possibilidade da rememoração de uma representação - a consciência que chamamos de "mediata"' - era dependente das associações linguísticas, hipótese que é mantida no esquema do aparelho psíquico do capítulo 7 e naquele apresentado em 1915, embora o mecanismo através do qual a representação de palavra levaria à produção de qualidades sensoriais seja pensado de forma diferente em cada um desses textos. Procuramos argumentar por que a hipótese formulada no Projeto permite compreendermos a razão pela qual a rememoração dependeria exclusivamente das palavras, ao contrário daquela elaborada posteriormente.

No Projeto, a possibilidade de uma parte das representações permanecer sem acesso à consciência por não estar associada a palavras já está comtemplada, mas, ali, apenas a presença ou não de vínculo com as palavras diferenciaria a representação suscetível e a insuscetível de consciência. Essa diferenciação torna-se mais complexa no capítulo 7, com a hipótese de que o psíquico suscetível e o insuscetível de consciência consistiriam em tipos de processos diferentes (o primário e o secundário), o que faria com que eles apresentassem características peculiares. No capítulo 7, Freud sustenta que não bastaria uma representação estar associada a palavras para que ela pudesse se tornar consciente: além dessa associação, seria necessário ainda que a representação possuísse intensidade superior a certo nível e que não fosse barrada pela censura atuante entre os sistemas pré-consciente e consciente. 
Em Além do princípio do prazer e em $O$ ego e o id, Freud passa a situar a consciência juntamente com a percepção, na extremidade oposta do aparelho em que se encontrava antes, o que modifica a hipótese anterior de que a constituição da representação precederia o tornar-se consciente. Freud também deixa de vincular a possibilidade de rememoração exclusivamente à associação com representações de palavra, ao reconhecer que esta pode se dar também a partir da ativação de imagens visuais. No entanto, é mantida a hipótese de que seria a associação com representações de palavra que tornaria parte de nossa memória suscetível de consciência. Há, portanto, uma contradição interna na teoria que acabou não sendo resolvida. Apesar de as relações entre a percepção, a memória e a consciência serem alteradas nessa etapa final da teoria, parece ser mantida a hipótese de que as nossas representações não seriam cópias pontuais dos estímulos que incidissem sobre a periferia de nosso sistema nervoso, assim como a hipótese de que nem todas as nossas percepções seriam apreendidas conscientemente.

Podemos dizer que a relação entre a representação e a consciência se configura como um dos problemas centrais da teoria metapsicológica freudiana, cuja elucidação está ainda longe de ter sido plenamente alcançada. O problema colocado por essa relação é uma consequência direta da introdução do conceito freudiano de um inconsciente psíquico ativo e casualmente eficaz. Se uma parte significativa dos processos psíquicos não é consciente, se essa parte determina, de uma forma ou de outra, o curso daquilo que ocorre na consciência e se o campo fenomenal que constitui esta última como que emerge a partir dos processos quantitativos e dinâmicos que formam o inconsciente, então a relação entre domínio mais amplo da representação (ou da mente) e aquele, mais restrito, da consciência, é uma questão conceitual que não pode ser ignorada pela teoria. A extensão e o detalhe com que Freud trabalhou esse problema, em suas diversas modificações - relação entre consciência e linguagem, entre consciência e percepção, entre consciência e memória, entre outras -, mostram que ele tinha plena consciência de sua importância. Foi essa extensão e esse detalhe que procuramos reconstruir aqui, a fim de evidenciar que a consciência, de forma alguma, é um problema menor da metapsicologia freudiana.

\section{REFERÊNCIAS}

CAROPRESO, F. (2001). Pensamento, linguagem e consciência nos textos iniciais de Freud. Paideia: Caderno de Psicologia e Educação, 11(20), p. 29-38.

. (2008a). O nascimento da metapsicologia: representação e consciência na obra inicial de Freud. São Carlos, EDUFSCar/FAPESP.

. (2008b). O inconsciente psíquico na metapsicologia freudiana: desenvolvimento e articulações conceituais. In: AIRES, Suely e RIBEIRO, Caroline (orgs.). Ensaios de filosofia e psicanálise. Campinas, Mercado de Letras, p. 107-128.

. (2008c). Representação, atenção e consciência na primeira teoria freudiana do aparelho psíquico. Natureza Humana: Revista de Filosofia e Psicanálise, 10(1), p. 47-72.

. (2010). Freud e a natureza do psíquico. São Paulo, Annablume/FAPESP.

FREUD, S.; BREUER, J. (1895). Studien über Hysterie. In: Gesammelte Werke. London, Imago, 1952. Vol. 1, p. 75-312.

. (1891). Zur Auffassung der Aphasien: eine Kritische Studie. Leipzig, Franz Deuticke. 
. (1895/1950). Projeto de uma Psicologia. In: GABBI JR, O. F. Notas a "Projeto de uma Psicologia": as origens utilitaristas da psicanálise. Rio de Janeiro, Imago, 2003.

. (1950). Fragmentos de la correspondencia com Fliess. In: Obras completas. Buenos Aires, Amorrortu Editores, 1998. Vol. 1, p. 211-322.

. (1900). Die Traumdeutung. In: Studienausgabe. Frankfurt, Fischer, 1982. Vol. 2.

. (1912). Einige Bermerkungen über den Begriff des Unbewussten in der Psychoanalyse. In: Studienausgabe. Frankfurt, Fischer, 1982. Vol. 3, p. 25-36.

. (1915a). Das Unbewusste. In: Studienausgabe. Frankfurt, Fischer, 1982. Vol. 3,

p. $119-162$.

1982. Vol. 3, p. 103-118.

(1915b). Triebe und Triebeschicksale. In: Studienausgabe. Frankfurt, Fischer,

. (1917). Metapsychologische Ergänzung zur Traumlehre. In: Studienausgabe. Frankfurt, Fischer, 1982. Vol. 3, p. 175-192.

. (1916-17). Conferencias de introducción al psicoanálisis. In: Obras Completas. Buenos Aires, Amorrortu Editores, 1998, p. 15-16.

. (1920). Jenseits des Lustprinzips. In: Studienausgabe. Frankfurt, Fischer, 1982.

Vol. 3, p. 213-272.

. (1923). El yo y el ello. In: Obras Completas. Buenos Aires, Amorrortu Editores,

1998. Vols. 1, p. 1-66.

. (1925a). Die Verneinung. In: Studienausgabe. Frankfurt, Fischer, 1982. Vol. 3, p.371-378.

1982. Vol. 3, p. 363-370.

. (1925b). Notiz über den Wunderblock. In: Studienausgabe. Frankfurt, Fischer,

GARCIA-ROZA, L. A. (2001). Freud e o inconsciente. Rio de Janeiro, Jorge Zahar Editor.

GOMES, G. (2003). A teoria freudiana da consciência. Psicologia: Teoria e Pesquisa, 19(2), p. 117-125.

LAPLANCHE, J.; PONTALIS, J. B. (1998). Vocabulário da psicanálise. São Paulo: Martins Fontes.

NATSOULAS, T. (2002). Freud and Consciousness: XI. A Different Interpretation Considered. Psychoanalysis and Contemporary Thought, 25(1), p. 29-66.

PORCHAT, P. (2005). Freud e o teste de realidade. São Paulo: Casa do psicólogo/FAPESP.

SIMANKE, R. T.; CAROPRESO, F. (2005). O conceito de consciência no Projeto de uma psicologia de Freud e suas implicações metapsicológicas. Trans/Form/Ação: Revista de Filosofia, 28(1), p. 85-108. 
SIMANKE, R. T. (2009). A formação da teoria freudiana das psicoses. São Paulo, Edição Loyola.

\section{NOTAS}

1. A autora agradece ao CNPQ pela Bolsa de Produtividade em Pesquisa.

2. Embora Freud pareça, as vezes, utilizar indistintamente as expressões "sistema nervoso" e "aparelho" (neuronal ou psíquico), estas podem ser distinguidas, considerando que "sistema nervoso" designa uma estrutura orgânica que possui realidade anatômica e fisiológica, enquanto que "aparelho neuronal ou psíquico" designa uma descrição exclusivamente funcional da atividade nervosa, naquilo em que as propriedades que essa atividade faz surgir podem ser consideradas como psíquicas.

3. Essa identificação entre aumento de excitação e desprazer, por um lado, e entre seu rebaixamento e prazer, por outro, passa a ser questionada por Freud a partir de certo momento de sua obra. Por exemplo, em Pulsões e seus destinos (FREUD, 1915b), ele afirma que essa relação deve ser mais complexa e que, por enquanto, permanece desconhecida. Na 22a Conferência de Introdução à Psicanálise (FREUD, 1916-1917), o autor volta a manifestar sua dúvida a respeito de uma identificação simples entre aumento de excitação e desprazer e sua diminuição e prazer. Em Além do princípio do prazer (FREUD, 1920), Freud sugere que talvez o ritmo da variação no nível de excitação seja determinante na produção das sensações de prazer e desprazer e não o valor bruto dessa variação.

4. Uma análise mais minuciosa dos problemas relativos à hipótese do sistema phi no Projeto pode ser encontrada em Simanke e Caropreso (2005).

5. As regras biológicas são postuladas por Freud para dar conta daqueles processos que não podem ser derivados do funcionamento do aparelho tal como este se constitui ao longo da ontogênese, tendo, portanto, que ser remetidos a tendências hereditárias, fixadas ao longo da evolução da espécie (filogênese).

6. Na carta a Fliess de 6 de dezembro de 1896 (Carta 52), Freud fala de uma "consciência secundária", para se referir a esse tipo de consciência.

7. O funcionamento regido unicamente pelo princípio de inércia, que se caracteriza pelo livre fluxo das quantidades de excitação nervosa entre os neurônios, tendo em vista a descarga mais imediata possível, consistiria no que Freud chama de processo primário. Com a substituição do princípio de inércia pela tendência à constância, o processo primário seria substituído pelo secundário. Nesse último, o fluxo da excitação estaria parcialmente inibido, de forma que certo nível de quantidade seria retido nos neurônios - em outras palavras, essa quantidade se encontraria, doravante, em um estado "ligado". Depois de estabelecido o processo secundário, o primário só voltaria a ocorrer nos sonhos e nos fenômenos patológicos (o que Freud denomina, então, processos primários póstumos).

8. Na verdade, a representação de phi e ômega encontra-se, no modelo do aparelho psíquico de 1900, consideravelmente limitada, com ambos sendo reduzidos, na prática, a extremidades ideais do aparelho, não consistindo mais em sistemas propriamente ditos. O que é, de fato, teorizado intensivamente aí, são as funções do que, em 1895, constituía o sistema psi do manto, repartido numa pluralidade de subsistemas de memória. É nesse sentido que o aparelho do capítulo 7 pode ser considerado "psíquico" e não mais "neuronal”: ele se restringe a considerar os processos estritamente psíquicos - isto é, representacionais - do modelo mais abrangente do Projeto.

9. Em suas obras posteriores, Freud chamou esse princípio de “princípio do prazer”.

10. Afirmações como essa e a precedente parecem totalmente enigmáticas se não se tivesse em vista a teoria do Projeto: elas deixam claro que as hipóteses neurológicas do Projeto não foram abandonadas ou totalmente substituídas por hipóteses psicológicas, como em geral se considera. 
11. Na seguinte passagem, por exemplo, Freud afirma: "Se pudéssemos confirmar que, nos sistemas psi, memória e qualidade para a consciência se excluem entre si, nos abriria uma promissora perspectiva sobre as condições das excitações da excitação nos neurônios" (FREUD, 1900, p. 533).

12. Garcia-Roza (2001) considera que o pré-consciente e o consciente constituem, no capítulo 7, um mesmo sistema. No entanto, Freud os diferencia claramente: tratar-se-ia de dois sistemas separados, os quais estariam em estreita conexão. Em alguns dos artigos metapsicológicos de 1915, Freud manifesta sua dúvida quanto a distinguir ou não entre esses dois sistemas, mas ele acaba concluindo, no Complemento metapsicológico à doutrina dos sonhos (FREUD, 1917), que é preciso mesmo manter essa diferenciação.

13. Ao contrário do que afirmam Laplanche e Pontalis (1998), a atenção não é uma função do sistema consciente. Em algumas ocasiões, Freud usa o termo "atenção da consciência”, mas, na verdade, a atenção é uma função do Pcs, como demonstra a seguinte afirmação: "O sistema Pcs não só bloqueia o acesso à consciência, mas preside o acesso à motricidade voluntária e dispõe do envio de uma energia de ocupação móvel, uma parte da qual nos é familiar como atenção" (FREUD, 1900, p.602). Essa "energia de ocupação móvel” é um indício de como o pré-consciente de A interpretação dos sonhos herda as funções do eu do Projeto - que desaparece em 1900 - que lá se definia como uma massa de neurônios de ocupação permanente que era, então, empregada em "ocupações laterais" capazes de influírem no curso dos processos associativos, de inibi-los e/ou redirecioná-los.

14. No sonho, devido ao cessar parcial da atividade pré-consciente, o processo primário seria liberado e tentaria alcançar a consciência e a motricidade pela via progressiva. Como o Pcs barraria essa tentativa, o processo inconsciente, atraído pelas representações próximas ao sistema perceptivo, tomaria o sentido regressivo e acabaria produzindo uma alucinação.

15. Em $O$ inconsciente, Freud afirma: “(...) a existência de uma censura entre Pcs e Cs nos adverte que o tornar-se consciente não é um ato de percepção, mas que provavelmente se trata também de uma sobreocupação, um progresso posterior da organização psíquica” (FREUD, 1915a, p. 152). 